\title{
2.1
}

\section{ESTETISKA PERSPEKTIV MED KULTUR- OCH KONSTVETENSKAPLIGA METODER}

\author{
Johan Knutsson, Ingalill Nyström och Anneli Palmsköld
}

Detta kapitel behandlar de estetiska perspektiven analyserade genom kultur- och konstvetenskapliga teorier och metoder. En stor del av inredningarna och föremålen har i museipraktiker och i tidigare forskning betecknats som folkkonst. De har använts för att kategorisera olika kulturhistoriska företeelser, men även ideologiskt för att ringa in en befolkningsgrupp vars hantverkande har betraktats och beskrivits av andra än utövarna själva. Begreppet folkkonst är en akademisk konstruktion, något som varit föremål för debatt i stort sett ända sedan det lanserades i forskningen i slutet av 1800-talet (Bringéus 2005; Knutsson 2001). Även adjektivet "folklig" är komplicerat, mångtydigt och knutet till olika värderingar, men har trots allt etablerats och har främst använts för att beskriva materiell och immateriell kultur i det förindustriella samhället (Palmsköld 2007).

\section{Den visuella gestaltningens förutsättningar}

Kapitlet genomsyras av vår gemensamma teoretiska utgångspunkt ${ }^{10}$ att den konstnärliga utvecklingen präglas av individernas (hantverkares och konstnärers) vilja och förmåga till estetisk gestaltning, balanserad mot förutsättningar som tillgång till material, materialets egenskaper, tillgänglig teknologi, hantverkskunskap och erfarenhet. Till detta kan läggas den ekonomiska kontexten och beställarens önskemål.

Alla utövare av konst, hantverk och design förhåller sig till material

10. Denna teoretiska utgångspunkt har vi alla använt och problematiserat i våra respektive avhandlingar, som behandlar olika empiriska fält inom folkligt hantverk och gestaltning (Knutsson 2001; Palmsköld 2007; Nyström 2012). 
och teknik, man arbetar med det eller emot det. Men särskilt tydligt är detta i folkkonsten och slöjden där arbetet oftast börjar i tillgängligt material och möjlig teknik och där man arbetar med materialet, inte mot det. Ett mönster eller motiv anpassas och förändras när det överförs från ett material till ett annat, från en teknik till en annan. Fast exakt hur förändringen tar sig uttryck går aldrig att förutse. Kreativiteten är individuell. Konstnärens eller hantverkarens egen vilja gör att resultatet trots allt inte blir exakt lika från fall till fall även om inspirationskällorna, materialet, tekniken, funktionen och de ekonomiska villkoren varit desamma.

Oavsett vilken föremålskategori som undersöks är det visuella uttrycket och de estetiska lösningarna beroende av en mängd variabler som: material, teknik, verktyg, personliga stilistiska karaktärsdrag, handlag, motivval, komposition, influenser, konventioner, utbildning och erfarenheter. Måleriet och det fria broderiet inbjuder som konstnärliga medier till ett mer fritt skapande än till exempel vävning som är bunden vid en på förhand iordningställd varp. En målare kunde kombinera olika motiv, repertoarer, tekniker och verktyg samt figurativt frihandsmåleri, schablonmåleri och tryckta tapeter och därigenom variera det slutliga visuella uttrycket. Utan att behöva uppdatera sitt tekniska kunnande eller utöka sin uppsättning av verktyg och färger kunde målaren lätt övergå från barockens akantus till rokokons rocaille - om hen bara fick veta hur en sådan såg ut. Och improvisation kunde ske under arbetets gång.

De skilda hantverken styrs av sina specifika villkor. En målad yta på vägg kan till exempel lätt målas om, och målas över om det skulle behövas. På motsvarande sätt är det möjligt att sprätta upp ett broderi och sy om eller att dra upp en virkad spets och göra om den. En möbel kan målas om - men sällan görs ingrepp i dess konstruktion. Detsamma gäller för vävnader.

\section{En estetik för sig}

Det finns några globalt giltiga och allmänna drag som präglar all folkkonst - och mycket av den övriga konsten - i hela världen. Några av dessa är:

- favoriseringen av en ornamental, geometrisk dekor

- sättet att komponera och fördela dekoren adderande över 
den till buds stående ytan, gärna symmetriskt utifrån en tänkt mittlinje

- betoningen av den tvådimensionella ytan istället för en illusion av tredimensionell djupverkan

- viljan att ge människor, djur och växter en dekorativ, ornamental och stiliserad form.

Detta sätt att beskriva och analysera universella principer för komposition har utvecklats och tillämpats av konsthistoriker och teoretiker som till exempel Ernst Gombrich (1979) och på senare tid även filosofen Mikkel Tin $(2007,2011)$. De globalt förenande dragen har fram till 1990-talet sällan lyfts fram i tidigare studier av folkkonst. Istället har folkkonst studerats som nationella, regionala och lokala företeelser.

Den folkliga visuella kulturen har ibland beskrivits som "naiv och enkel". Det som avses är då inte främst kvalitet och skicklighet i utförandet, hanteringen av material och teknik, utan här åsyftas förenklingen och renodlingen av formerna. Uttrycket har förknippats med en oskolad hantverkares eller konstnärs direkta sätt att gestalta ett motiv. Detta är en bedömning gjord ur ett utifrånperspektiv. Den bygger på uppfattningen om att den västerländska konsten, såsom denna utvecklats från renässansen där saker avbildas som de framstår i verkligheten, realistiskt, är den mest sofistikerade och högst utvecklade. Ur ett globalt perspektiv är detta sätt att gestalta något visuellt relativt marginellt. Blommor, blad, djur, fåglar, landskap, byggnader och inte minst människofigurer har ibland varit förebilder som i nästa steg har stiliserats och abstraherats till mönster och ornamentik (jfr Glassie 1999). Det finns också exempel på analyser som visar att abstraherade former istället följer de tekniska möjligheter som olika hantverkstekniker erbjuder (Palmsköld 2007). I detta avseende, de målade mönstrens abstraktionsnivå, skiljer sig hälsingegårdarna något från annan folklig inredningskultur. Förstugor och festrum har ibland marmoreringar och ådringsmåleri som på ett naturalistiskt vis imiterar äkta marmor och ädelträ.

\section{Föremålsanalys}

Att använda föremål som historisk källa och utgångspunkt för analys är vanligt inom Art Technological Source Research, ATSR, och även inom vissa humanistiska discipliner (se s. 221f). Men de räcker sällan 
ensamma. Det är därför viktigt att använda många olika källor tillsammans, för att nå ökad kunskap. Att bara utgå från texter som källmaterial inom till exempel hantverksforskning innebär att många dimensioner undanskyms. Textilvetaren Pernilla Rasmussen hänvisar till folkloristen Henry Glassie när hon skriver att "föremålen innehåller mening som inte formuleras i skriftligt källmaterial men som lämnat spår i tingen" (Rasmussen 2010:19). Etnologen Marianne Larsson lyfter fram vikten av att vara i närkontakt med föremålen, att aktivt arbeta med de sinnesintryck som tingen ger, det vill säga att lukta och känna på dem (Larsson 2008:31). Ett sätt att beskriva metoden är att som etnologen Charlotte Hyltén-Cavallius tala om "känselseende" som ett sätt att beteckna "det vi 'ser' med händerna": "Ett känselseende kan uppfatta sådant som egenskapen hos en form eller ytans textur" (Hyltén-Cavallius 2007:26). Att umgås med föremål på detta sätt öppnar upp för en djupare förståelse för bland annat material, tekniker, tillverkningsprocesser, bruks- och återbruksaspekter (jfr Palmsköld 2007 , 2013). Metoden är särskilt lämpad för att besvara forskningsfrågor som handlar om historiska hantverksprocesser och om konserveringsvetenskapligt grundad materialkaraktärisering. De utmaningar som metoden ger handlar framför allt om hur översättningen av sinnesförnimmelser kan ske i text (se Palmsköld 2007). Den har också kritiserats för att i alltför stor utsträckning utgå från den enskilde forskarens egna upplevelser av tingen. Att utgå från enskilda föremål kan enligt kritikerna innebära att kontextualiseringen går förlorad. Detta är ett klassiskt och ofta återkommande diskussionsämne inom museipraktiken och något som forskare som arbetar med föremålsanalys är medvetna om och ofta är det just kontexten som ligger i fokus.

De föremål ${ }^{11}$ som har analyserats i projektet ägs av museer, hembygdsgårdar och privatpersoner. När det gäller historiska samlingar vid institutioner och i ideella föreningar, är föremålen numrerade och katalogiserade och uppgifterna utgör en viktig del av informationen om respektive föremål (Palmsköld 2007:37ff). Katalogen (accessionskatalog tillsammans med katalogkort) är ett sätt att hålla reda på samlingar, viktigt inte minst med tanke på försäkringar, och beskrivningar av föremål syftar i första hand till att kunna identifiera dem. Tidigare och nuvarande ägandeförhållanden är viktiga uppgifter samt eventuella

11. Med föremål avses här både inredningsmåleri som har studerats in situ och enskilda föremål som verktyg, råmaterial, möbler och textilier. 
villkor förknippade med förvärvandet av föremålet. Uppgifter om hur föremålet förvärvades samt om dess tidigare ägare vittnar om de nätverk som hembygdsgårdar och museer ingår och ingick i. I museernas fall var det vanligt att samma intresserade privatperson eller handlare sålde föremål till flera museer. Men katalogen är också ett sätt att addera information som är svår att utläsa ur föremålet självt. Tanken är att den är sökingången till föremålssamlingen, på samma sätt som bibliotekskatalogen leder fram till bokbeståndet. När det gäller privata ägare finns det sällan samma typ av skrivna dokumentation. Däremot kan det finnas muntliga uppgifter om proveniens och personhistorik, som ibland också kan kompletteras med genealogiska uppgifter.

Att genomföra föremålsanalys innebär att inledningsvis notera deras fysiska kännetecken, så som de framstår för forskaren när hen undersöker dem med sina sinnen. Därefter dokumenteras föremålet samt den skriftliga och muntliga information som finns tillgänglig i ord och bild. Den samlade dokumentationen ligger till grund för analys och tolkning, i detta fall en tvärvetenskaplig sådan som tillåter att flera perspektiv synliggörs. Analysen kan göras med naturvetenskaplig metodik och till exempel innebära mikroskopering för att fastställa vilka fibrer som ingår i en textil eller att kemiska analyser utförs för att förstå vilka bindemedel och pigment som har använts i ett måleri. De frågor som ofta ställs till föremål handlar om:

- material och tillverkningsteknik (tillverkning)

- funktion och användning (bruk och återbruk)

- form, design och dekoration (estetik)

- föremålets kontext och historia (inklusive dess olika värden i de sammanhang de har ingått och ingår)

I det följande kommer vi att fokusera på frågor om form, design och dekoration, det vill säga de estetiska aspekterna av Hälsinglands inredningskultur.

\section{Stilhistorisk analys}

Inom konstvetenskap har stilhistorisk analys använts för att skapa hållpunkter för datering. Metoden har främst tillämpats på föremålsbestånd som följer en normativ stilutveckling, det vill säga den stilkronologi som konstruerades för den västerländska konsthistorien under sent 
1800-tal och tidigt 1900-tal. Men att använda den som dateringskälla för det folkliga materialet leder lätt på avvägar. I tidigare forskning användes begreppet retardering för att beskriva hur föremål tillkomna i folkliga miljöer stilmässigt formades med en viss tidsmässig eftersläpning. Detta sätt att beskriva estetik i folkliga sammanhang bortser från de estetiska övervägningar som folkkonstnärer faktiskt gjorde. Det kan vara mer relevant och värdeneutralt att tala om stilkombinationer och stilanakronismer (Knutsson 2001).

En annan tongivande idé var tidigare tanken att nya stilar och estetiska lösningar sipprade ned från eliten till samhällets lägre skikt. Detta skikt ansågs inte till fullo förstå hur stilarna skulle tillämpas på ett "korrekt" sätt. Forskare i början av 1900-talet beskrev det som "sjunket kulturgods" ("gesunkenes Kulturgut") och såg det som en benägenhet hos bönderna att vilja efterlikna något utan att riktigt kunna. Båda begreppen, stilretardering och sjunket kulturgods, har sedan länge övergetts.

Det finns tillfällen då den stilistiska analysmetoden kan ge bonuseffekter utöver möjligheten till en trovärdig datering. Genom den stilistiska analysen friläggs ibland detaljer, som dräkt- och hårmode hos de avbildade figurerna, som annars kanske skulle förbigåtts om föremålet varit försett med en skuren eller stämplad datering. Stilhistorisk analys kan visa hur hantverkaren eller konstnären förhåller sig till sitt inspirationsmaterial - fritt, självständigt och ändå medvetet i förhållande till sina förlagor. Hälsinglands folkliga inredningskultur skiljer sig från den i andra landskap genom en relativt tydlig följsamhet gentemot identifierbara konststilar. Förhållandet mellan ett borgerligt stilideal och det för hälsingebonden identitetsskapande är en aspekt som förtjänar att lyftas fram.

\section{Konnässörskapsanalys}

I såväl föremålsanalys som i stilhistorisk analys krävs djupa och breda kunskaper, förtrogenhet med materialet samt "en stor erfarenhet av stora mängder föremål som tillsammans bygger en specialistkunskap" (Rasmussen 2010:20). Detta brukar kallas konnässörskap och kan innebära möjligheter till identifikation och attribuering av verk till specifika upphovspersoner eller -grupper (Knutsson 2001). En konnässörskapsanalys kan också innebära igenkänning och jämförelse mellan olika formspråk, tekniska lösningar och materialval. Analysen kan ibland ge indikationer på en konstnärs skolning, beställarens förutsättningar, 
samt ekonomiska och geografiska faktorer vilka i sin tur påverkar teknik, material, utförande och kvalitet.

Kritik har framförts att konnässörskapsanalysen framstår som subjektiv och grundad på ett slags intuition hos kännaren, konnässören, och att det är svårt att vetenskapligt argumentera för de slutsatser som dras. Vi menar dock att konnässörskapet är en tillförlitlig metod, men att den förutsätter att de särdrag som identifieras som särskiljande beskrivs verbalt på ett sätt som är möjligt att kommunicera, bedöma och granska. Det måste gå att i ord frilägga, definiera och beskriva vad som gör ett verk till ett verk av en viss person, eller från ett visst område, att kunna identifiera detaljer avgörande för attribueringen av en anonym målning, möbel eller textil till en viss namngiven person. I måleriet kan det till exempel handla om sättet att återge siffror och bokstäver. Där har vi idag större möjligheter än någonsin tidigare genom digitala bildbanker som tillåter jämförelser av ett stort antal föremål. Likaså har vi idag större möjligheter än tidigare till släktforskning som hjälper oss att påvisa samband mellan olika hantverkare och de platser där de verkat. Därutöver finns ytterligare en faktor som varit av en särskild betydelse i just det nu aktuella projektet. Genom kemisk materialkategorisering av målade signerade verk läggs grunden för en säkrare attribuering (Nyström 2012). På så sätt kan konstnärers val av tekniker och målarmaterial som pigment och bindemedel ge ny kunskap som tillsammans ger en fylligare och säkrare bild av konstnärskapet och dess kontext. Analysen av material och teknik hjälper oss att styrka eller tillbakavisa de tidigare gjorda attribueringarna med en helt annan trovärdighet än om vi enbart varit hänvisade till stilhistorisk analys och konnässörskap.

En målares personliga stil och hens målaruttryck är beroende av materialval, målarteknik, motivval, influenser, konventioner och utbildning. Men också av målarens erfarenhet, skicklighet, personliga penselskrift, drivenhet, temperament och val av komposition och repertoar. Genom att kombinera olika motiv, repertoarer, målartekniker och verktyg samt genom att använda figurativt frihandsmåleri med non-figurativt schablonmåleri och köpta tapeter, ges stora möjligheter till varierande visuella uttryck. Detta behärskade de innovativa och kreativa målarna i Hälsingland.

I såväl måleri som träskärning och fritt broderi kan det vara relativt lätt att avläsa en personlig handstil. Betydligt svårare är det i andra mer bundna tekniker, som till exempel schablonmåleri och vävning. Men även i det till synes bundna finns möjlighet till observation av individu- 
ella särdrag. Eftersom varken målare, träskärare eller väverskor normalt signerade sina verk kan det vara med hjälp av den personliga stilen och det personliga handlaget som upphovspersonen kan identifieras och visas hur två verk, hur lika de än kan tyckas, visar sig vara utförda av två personer.

Poängen med att rikta sökarljuset mot de olika individuella handlagen handlar om att få kunskap om vem som har gjort vad. Drivkraften bakom konnässörskapsanalysen som metod är och har varit viljan att hitta och identifiera en specifik namngiven och spårbar människa bakom verket. På så sätt ökar värdet både kulturhistoriskt och ekonomiskt - konnässörskapets pådrivande faktor när metoden utvecklades för hundra år sedan var de stigande priserna på konstmarknaden - och därmed skapas förutsättningar för att föremålen kan uppskattas och bevaras. Den ekonomiska värdeökningen gäller dock i första hand måleri, sällan textilier (jfr Palmsköld 2005). Påvisandet av de personliga handlagen ger oss en påminnelse om att måleri, textil och annan folkkonst har utövats och utvecklats av och genom enskilda individer - inte av ett kollektiv anonyma med ett gemensamt folkligt "kynne" som tidigare gjorts gällande.

När det gäller folkkonst och slöjd har denna kategori i första hand kartlagts och systematiserats utifrån geografi, enligt en indelning i olika ortskaraktäristiska skolor och uttryck. En förutsättning här har varit att kunna urskilja inte bara en individs handlag utan en hel grupps olika handlag. Det krävs både detaljskärpa och överblick för att här kunna driva konnässörskapet som metod.

Såväl konnässörskapsanalys som material- och teknikanalyser räcker sällan som bevis för vem som gjort vad. På senare tid har förekomsten av nätverk målare emellan uppmärksammats. En målare har tagit hjälp av en annan målare för att tillsammans fullborda ett uppdrag - målare har alltså samverkat snarare än konkurrerat. Detta komplicerar frågor som handlar om attribuering. Flera målare kan ha doppat penseln i samma färg, använt samma stämplar och schabloner. Om de har målat i samma rum, har de också anpassat motivval och stil för att skapa ett enhetligt uttryck. Många exempel finns på det i hälsingegårdarna.

Det konnässörskap som bygger på en kombination av skriftligt källmaterial om proveniens, vetenskapliga undersökningar av material och teknik och kännarens kunskap om olika hantverkares och konstnärers personliga manér och favorisering av motiv, mönster och arbetssätt har de största chanserna att lyckas. Slutligen måste återigen betonas att 
konnässörskapet och den stilistiska bedömningen, som ingår i föremålsanalysen, bara är en del av helhetsbedömningen.

\section{Referenser}

\section{Tryckta källor}

Bringéus, Nils-Arvid (2005). Folkkonst och forskning: en tillbakablick. Formgivare: folket. Fataburen: kulturhistorisk tidskrift. Stockholm: Nordiska museet, s. [16]-29.

Glassie, Henry H. (1999). Material Culture. Bloomington, Indiana: Indiana University Press.

Gombrich, E. H (1979). The Sense of Order: A study in the psychology of decorative art. Ithaca: Cornell U.P.

Hyltén-Cavallius, Charlotte (2007). Traditionens estetik: spelet mellan inhemsk och internationell hemslöjd. Diss. Stockholm: Stockholms universitet.

Knutsson, Johan (2001). Folkliga möbler: tradition och egenart. En stilanalytisk studie av renässans- och barockdrag i den svenska folkliga möbelkonsten. Diss. Stockholm: Stockholms universitet.

Larsson, Marianne (2008). Uniformella förhandlingar: hierarkier och genusrelationer $i$ Postens kläder 1636-2008. Diss. Stockholm: Stockholms universitet.

Nyström, Ingalill (2012). Bonadsmåleri under lupp: spektroskopiska analyser av färg och teknik isydsvenska bonadsmålningar 1700-1870. Diss. Göteborg: Göteborgs universitet. Tillgänglig på: http://hdl.handle.net/2077/30154

Palmsköld, Anneli (2005). Hängkläden, drättar, lister och takdukar: inredningstextilier i ny belysning. I: Svensson, Birgitta \& Louise Waldén (red.). Den feminina textilen: makt och mönster. Stockholm: Nordiska museets förlag, s. 141-162.

Palmsköld, Anneli (2007). Textila tolkningar: om hängkläden, drättar, lister och takdukar. Diss. Lund: Lunds universitet.

Palmsköld, Anneli (2013). Textilt återbruk: om materiellt och kulturellt slitage. Möklinta: Gidlunds.

Rasmussen, Pernilla (2010). Skräddaren, sömmerskan och modet: arbetsmetoder och arbetsdelning i tillverkningen av kvinnlig dräkt 1770-1830. Diss. Uppsala: Uppsala universitet.

Tin, Mikkel B. (2007). De forste formene: folkekunstens abstrakte formspråk. Oslo: Novus forlag.

Tin, Mikkel B. (2011). Spilleregler og spillerom: tradisjonens estetikk. Oslo: Novus. 